Jurnal Basicedu Volume 5 Nomor 1 Tahun 2021 Halaman 367-375

JURNAL BASICEDU

Research \& Learning in Elementary Education

https://jbasic.org/index.php/basicedu

\title{
Efektivitas Pembelajaran Daring di Masa Pandemi COVID 19 Bagi Mahasiswa Universitas PGRI Yogyakarta
}

\author{
Jagad Aditya Dewantara ${ }^{1}$, T Heru Nurgiansah ${ }^{2}$ \\ Universitas Tanjungpura, Indonesia ${ }^{1}$ \\ Universitas PGRI Yogyakarta, Indonesia ${ }^{2}$ \\ Email : jagad02@fkip.untan.ac.id ${ }^{1}$, nurgiansah@upy.ac.id ${ }^{2}$
}

\begin{abstract}
Abstrak
Wabah Corona membuat segala hal mengalami perubahan rutinitas, termasuk dalam hal pendidikan. Dulu pembelajaran di perguruan tinggi dilaksanakan secara tatap muka, akan tetapi sekarang pembelajaran harus dilaksanakan secara online. Tujuan penelitian ini adalah untuk mengetahui seberapa besar efektivitas pembelajaran secara daring dimasa pandemi covid 19 bagi mahasiswa Universitas PGRI Yogyakarta. Penelitian ini menggunakan model Kuantitatif dengan metode survei. Responden dari penelitian ini berjumlah 1.000 mahasiswa. Hasil penelitian ini menunjukan bahwa 79\% mahasiswa menginginkan pembelajaran secara tatap muka, sedangkan hanya $1 \%$ saja mahasiswa yang menginginkan pembelajaran daring, sehingga dapat disimpulkan bahwa pembelajaran daring secara terus menerus selama masa pandemi ini sangat tidak efektif.
\end{abstract}

Kata Kunci: Pembelajaran Daring, Covid-19, Mahasiswa

\begin{abstract}
An outbreak of Corona made things undergo a change of routine, including in terms of education. In the past, learning in college was conducted face-to-face, but now learning should be implemented online. The aim of this research is to know how much effectiveness of online learning during the pandemic 19 for the students of PGRI Yogyakarta University. The study used quantitative models with survey methods. Respondents of this study amounted to 1,000 students. The results of this study showed that $79 \%$ of students wanted to study face-to-face, while only $1 \%$ of students wanted online learning, so it could be concluded that continuous online learning during the pandemic is very ineffective.
\end{abstract}

Keywords: Online Learning, Covid-19, Student

Copyright (c) 2021 Jagad Aditya Dewantara, T Heru Nurgiansah

Corresponding author:

Address : Jalan Prof. Dr. H. Hadari Nawawi, Pontianak 78124

Email : jagad02@fkip.untan.ac.id

DOI: https://doi.org/10.31004/basicedu.v5i1.669

ISSN 2580-3735 (Media Cetak)

ISSN 2580-1147 (Media Online) 


\section{PENDAHULUAN}

Dinamis merupakan sifat zaman yang artinya terus bergerak menuju peradaban yang lebih sempurna. Salah satu indikator berubahnya zaman adalah penggunaan teknologi informasi. Perkembangan teknologi informasi memiliki pengaruh besar terhadap perubahan dalam setiap bidang kehidupan (Handarini \& Wulandari, 2020). Berbagai bidang kehidupan mengalami metamorfosis ke arah pembaruan yang mutlak terjadi, misalnya pendidikan. Pendidikan ibarat wadah untuk membentuk warga negara yang cerdas dan mampu menyelesaikan segala persoalan kehidupan. Pendidikan merupakan sebuah produk yang dihasilkan untuk menggapai cita-cita nasional (T. H. Nurgiansah, 2019). Cita cita nasional negara Indonesia termaktub dalam pembukaan UndangUndang Dasar 1945 yakni mencerdaskan kehidupan bangsa terlebih negara kita punya visi generasi emas pada 2045 mendatang sebagai perayaan 100 tahun kemerdekaan Indonesia.

Namun seiring berjalannya waktu, akhir tahun 2019 berasal dari Wuhan China muncul virus bernama corona atau Covid-19 yang akhirnya menyebar ke seluruh dunia tanpa terkendali yang merepotkan seluruh negara baik itu negara maju maupun negara berkembang, termasuk Indonesia yang pada akhirnya Covid 19 ini ditetapkan sebagai wabah pandemi oleh World Health Organization (WHO) pada 12 Maret 2020 (Novia Nur Kharisma dkk, 2020). Covid-19 adalah penyakit jenis baru yang belum pernah diidentifikasi sebelumnya pada manusia $(\mathrm{Ni}$ Komang Suni Astini, 2020). Virus ini berbeda dengan virus sebelumnya yang juga berasal dari negara China seperti flu burung atau flu babi yang penularannya melibatkan hewan.

Pandemi Covid-19 telah memberikan dampak besar pada berbagai bidang (Solviana,
2020). Salah satu bidang yang berdampak akibat Covid 19 di Indonesia adalah bidang pendidikan (M Ardi Sulata \& Abdul Aziz Hakim, 2020). Tak sedikit sekolah bahkan perguruan tinggi yang akhirnya menutup rutinitas akademiknya demi memutus mata rantai penularan Covid-19 yang sampai dengan saat ini sudah menjangkit puluhan juta orang di seluruh dunia, dan yang lebih mengerikannya lagi bahwa belum ditemukannya penawar atau vaksin untuk menyembuhkan virus ini.

Selanjutnya pihak Kementerian Pendidikan dan Kebudayaan Pemerintah telah melarang perguruan tinggi untuk melaksanakan perkuliahan tatap muka (Sadikin et al., 2020). Bukan tanpa alasan, menutup perguruan tinggi tidak serta merta menghentikan proses belajar, menutup kampus tidak berarti mendeskriditkan pendidikan, menghentikan perkuliahan bukan berarti tidak peduli dengan masa depan bangsa, tapi ini semua demi kebaikan bersama agar pandemi Covid-19 ini segera berakhir dan kehidupan di kampus bisa kembali normal karena aktivitas belajar merupakan suatu hal yang penting (Titi Rohaeti; Sumliyah, 2020).

Dengan ditiadakannya aktivitas perkuliahan tatap muka maka kuliah online menjadi solusi untuk tetap menjalankan kegiatan belajar-mengajar di tengah penyebaran virus corona (Purwanti \& Krisnadi, 2020). Pembelajaran daring merupakan solusi untuk tetap melaksanakan kegiatan belajar mengajar (Rachmat \& Krisnadi, 2020). Dimasa pandemi ragam alternatif penawaran aplikasi pembelajaran online kian laku (Sherina, 2020). Pembelajaran secara online atau daring (dalam jaringan) dilakukan melalui berbagai aplikasi (Suhada et al., 2020). Beragam pilihan aplikasi untuk perkuliahan daring diantaranya zoom, googleclassroom, email, dll. Perubahan kebiasaan perkuliahan ini tidak serta merta tanpa masalah. 
Perubahan metode pembelajaran dengan cara klasikal dan tatap muka menjadi metode online mendapatkan berbagai reaksi dari mahasiswa (Kusnayat et al., 2020).

Tidak sedikit mahasiswa yang mengeluh dengan pembelajaran online. Selain menambah beban biaya untuk keperluan kuota, mahasiswa pun tidak mendapat keringanan dalam hal pembayaran kuliah. Belum lagi ditambah dengan tugas yang membengkak menjadikan mahasiswa malas untuk sekedar menjalankan kewajibannya dalam mengerjakan tugas perkuliahan. Dengan sistem online diharapkan mahasiswa lebih terbantu untuk memperoleh pengetahuan dan belajar tanpa harus pergi ke kampus (Mulawarman, 2020). Sistem pendidikan jarak jauh menjadi salah satu solusi untuk mengatasi kesulitan dalam pembelajaran tatap muka (Yensy, 2020). Akan tetapi pelaksanaan pendidikan jarak jauh pada masa penyebaran pandemi Covid-19 menimbulkan berbagai persoalan (Ahmad, 2020). Salah satu contoh persoalan tersebut diantaranya baik dosen maupun mahasiswa masih kesulitan dalam mengoprasikan aplikasi daring tersebut.

Padahal penggunaan media online atau media berbasis multimedia merupakan salah satu solusi untuk membuat peserta didik mampu memahami materi pelajaran dengan baik agar materi yang disampaikan dapat terserap dengan sempurna (Mustakim, 2020). Sehingga pada masa pandemi ini Proses belajar mengajar harus dilaksanakan dalam jaringan (Satrio et al., 2020).

Sistem pembelajaran yang sangat berubah ini membawa dampak besar dalam dunia pendidikan (Simatupang et al., 2020). Hal ini akan menjawab apakah penggunaan teknologi mampu menggantikan peran pengajar atau justru pengajar tidak akan bisa digantikan oleh teknologi secanggih apapun.
Selain itu juga, kesulitan penguasaan dan pemahaman materi disebabkan oleh gangguan pengiriman informasi dosen ke mahasiswa, yang dapat terjadi dari berbagai faktor salah satunya adalah penggunaan media pembelajaran (Ferdiana, 2020). Media pembelajaran yang menarik dan menyenangkan akan mampu menghilangkan rasa bosan dalam pembelajaran. Perkuliahan daring mahasiswa memerlukan variasi tersendiri untuk menghilangkan kejenuhan. (Aan Widiyono, 2020). Selain penggunaan media pembelajaran yang menarik, dalam perkuliahan online, kreativitas dosen sangat diperlukan dalam pembelajaran guna menghindari rasa bosan (Hikmat et al., 2020).

Kendala yang paling sering muncul selama pelaksanaan pembelajaran online yaitu paket internet yang tidak dimiliki mahasiswa (Arizona et al., 2020). Wabah ini tidak hanya menyasar bidang pendidikan tetapi juga menyasar bidang ekonomi sehingga para orang tua dari mahasiswa mengalami kesulitan dalam membeli kuota internet. Selain itu masih banyak dosen yang hanya menyuruh mahasiswa mengumpulkan tugas lewat email misalnya. Kebanyakan tugas seperti ini hanya formalitas saja demi menggugurkan kewajiban mengajar, padahal dosen berperan melakukan review terhadap tulisan-tulisan yang dibuat oleh para mahasiswa (Darmalaksana et al., 2020). Tulisan dari tugas mahasiswa ini harus benar-benar dikoreksi untuk mengukur sejauh mana pemahaman mahasiswa dalam menyerap materi ajar yang disampaikan oleh dosen. Dosen pun harus memiliki kemampuan memilah dan memilih model dan media pembelajaran yang relevan untuk mengatasi kebosanan (T. H. Y. P. Nurgiansah, 2020).

Dengan melihat beragam fakta di atas, maka penulis melakukan penelitian untuk melihat sejauh mana efektivitas pembelajaran daring di masa 
pandemi Covid-19 bagi mahasiswa Universitas PGRI Yogyakarta yang terdampak virus corona.

\section{METODE}

Penelitian ini menggunakan pendekatan kuantitatif dengan metode survei. Survei ini dilakukan untuk bahan evaluasi pembelajaran secara daring. Teknik pengumpulan data menggunakan angket. Pengisian angket dilakukan secara online. Alasan pemilihan survei ini adalah agar peniliti khususnya bisa mengetahui secara pasti dan akurat tentang keefektivan pembelajaran daring. Secara keseluruhan jumlah populasi mahasiswa Universitas PGRI Yogyakarta adalah 4.475 orang yang tersebar dalam 24 program studi. Sampel dalam penelitian ini berjumlah 1.000 orang, dengan margin of error kurang dari $5 \%$.

\section{HASIL DAN PEMBAHASAN}

Untuk mengetahui seberapa besar efektifitas pembelajaran daring, maka peneliti mengajukan beberapa pertanyaan yang sangat relavan untuk diisi secara jujur oleh responden yang secara sukarela mau mengisi kuesioner yang sudah disiapkan. Berikut ini beberapa pertanyaan yang diajukan kepada responden:

1. Bagaimana tanggapan saudara sebagai mahasiswa Universitas PGRI Yogyakarta mengenai pembelajaran secara daring selama masa Pandemi Covid 19 atau kurang lebih hampir 1 tahun ini ?

Pertanyaan ini diajukan untuk melihat tingkat kepuasan mahasiswa selama pembelajaran daring atau pembelajaran online dilaksanakan. Kurang lebih selama 1 tahun atau 2 Semester pelaksanaan perkuliahan di Universitas PGRI Yogyakarta dilaksanakan secara online. Jika dipaparkan secara detail, dalam 1 semester mahasiswa mengambil 10 mata kuliah dengan total 24 sks dan tiap-tiap mata kuliah memerlukan 15 kali pertemuan itu artinya setiap mahasiswa setidaknya melakukan 300 kali pembelajaran online selama 2 semester. Tentu saja ini bukan jumlah yang sedikit. Kepuasan mahasiswa terhadap pembelajaran daring perlu diukur agar kedepan bisa di evaluasi apakah pelaksanaan perkuliahan daring ini efektif atau justru membuat mahasiswa kurang puas dalam perkuliahan. Kemudian tingkat kepuasan mahasiswa juga tentunya mempengaruhi kualitas pembelajaran itu sendiri. Berikut hasil survei terhadap kepuasaan mahasiswa dalam pembelajaran daring:

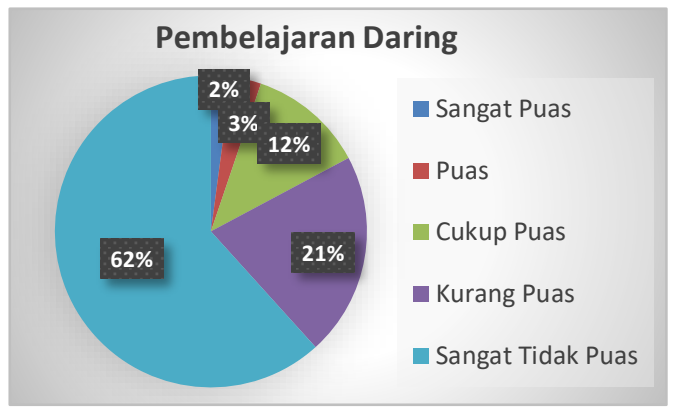

Gambar 1. Hasil Kepuasaan Mahasiswa Terhadap Pembelajaran Online

Berdasarkan gambar 1 tentang Hasil Kepuasaan Mahasiswa Terhadap Pembelajaran Online mengatakan bahwa sebanyak $62 \%$ mahasiswa merasa sangat tidak puas dengan pembelajaran online dan hanya $2 \%$ saja yang mengatakan sangat puas. Sisanya $3 \%$ merasa puas, $12 \%$ merasa cukup puas, dan $21 \%$ merasa kurang puas. Hal ini dapat disimpulkan bahwa pembelajaran online tidak disukai oleh sebagian besar mahasiswa UPY. Adapun untuk alasannya akan dipaparkan pada pertanyaan ke-4.

2. Media apa yang anda gunakan selama pembelajaran daring ?

Pertanyaan ini diajukan agar peneliti mengetahui aplikasi apa yang paling banyak digunakan selama pembelajaran daring. Beragam aplikasi untuk pembelajaran daring banyak 
pilihannya. Penentuan aplikasi yang digunakan mengambarkan efektivitas pembelajaran. Tentu saja aplikasi yang sangat efektif adalah aplikasi yang memungkinkan pembelajaran 2 arah secara langsung seperti Zoom atau Google Meet. Sedangkan aplikasi lainnya cenderung 1 arah seperti email. Berikut hasil survei terhadap aplikasi yang digunakan dalam pembelajaran daring:

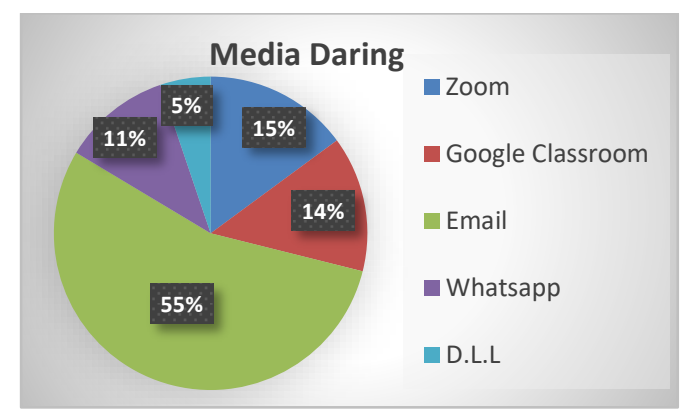

Gambar 2. Media Daring Yang Digunakan Dalam Pembelajaran Online

Berdasarkan gambar 2 tentang Media Daring Yang Digunakan Dalam Pembelajaran Online mengatakan bahwa aplikasi email berada diurutan pertama dengan jumlah 55\%. Padahal email tidak bisa digunakan untuk pembelajaran face to face berbeda dengan zoom yang lebih efektif hanya $15 \%$ saja responden yang menggunakannya. Ini artinya baik dosen maupun mahasiswa kurang melek teknologi. Sisanya $14 \%$ responden menggunakan aplikasi Google Classroom, 11\% Whatsapp, dan 5\% nya menggunakan aplikasi lain seperti googlemeet, Google Meet, Ruang Guru, dll.

\section{Bagaimana penerimaan materi yang} disampaikan oleh dosen melalui pembelajaran daring ?

Pertanyaan ini diajukan untuk mengetahui seberapa besar materi yang disampaikan dosen mampu diterima dengan baik oleh mahasiswa. Pertanyaan ini akan mampu menjawab tingkat keberhasilan pembelajaran daring yang dilakukan selama masa pandemi Covid-19. Berikut adalah hasil survei terhadap materi yang disampaikan oleh dosen kepada para mahasiswa:

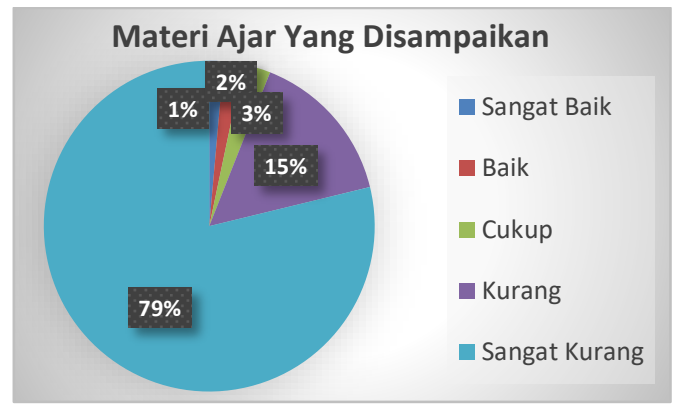

Gambar 3. Hasil Penyampaian Materi Ajar Dalam Permbelajaran Online

Berdasarkan gambar 3 tentang Hasil Penyampaian Materi Ajar Dalam Pembelajaran Online menunjukan bahwa $79 \%$ responden menjawab sangat kurang, $15 \%$ responden menjawab kurang, 3\% responden menjawab cukup, lalu $2 \%$ responden menjawab baik, dan sisanya menjawab sangat baik hanya $1 \%$ saja. Hal ini membuktikan bahwa selama pembelajaran daring, materi yang disampaikan oleh dosen tidak dapat terserap secara keseluruhan oleh mahasiswa. Hal ini bisa terjadi karena materi disampaikan secara terus menerus ataupun ada beberapa sub materi yang tidak tersampaikan. Hal ini wajar terjadi karena umumnya setiap mata kuliah terdiri dari 15 kali tatap muka. Dengan pembelajaran daring, beberapa dosen memadatkan materi ajar sehingga hanya 3 sampai 5 kali melakukan pembelajaran daring bahkan tidak sedikit dosen yang memangkas materinya sehingga tidak semua materi tersampaikan kepada mahasiswa.

4. Apa yang menjadi kekurangan dalam pembelajaran daring ?

Pertanyaan ini diajukan untuk mengetahui faktor apa saja yang menjadi penyebab tidak efektifnya pembelajaran daring. Beberapa faktor 
tersebut diantaranya rasa bosan, kuota internet, stabilitas jaringan, dan lain-lain. Pertanyaan ini akan mampu menjawab faktor penghambat yang paling dominan dalam pembelajaran daring. Berikut adalah hasil survei tentang kekurangan dalam pembelajaran daring:

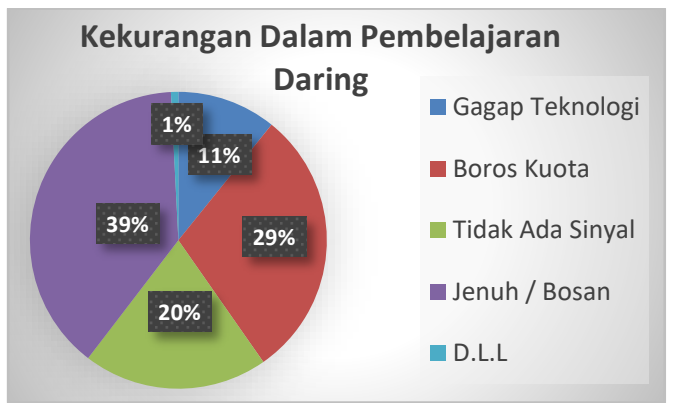

Gambar 4. Kekurangan Dalam Pembelajaran Daring

Berdasarkan gambar 4 tentang Kekurangan Dalam Pembelajaran Daring menunjukan bahwa $39 \%$ responden merasa jenuh / bosan, $29 \%$ responden mengeluhkan pemborosan kuota internet, $20 \%$ responden menjawab tidak ada sinyal, $11 \%$ responden menjawab gagap teknologi dalam arti tidak mengerti menggunakan beragam aplikasi daring, dan $1 \%$ responden menjawab lainnya seperti tidak punya Handphone, sibuk bekerja, sakit, dll. Tingkat kejenuhan yang tinggi adalah hal yang wajar terjadi tidak hanya bagi mahasiswa Universitas PGRI Yogyakarta tapi juga bagi mahasiswa di perguruan tinggi lainnya bahkan tidak hanya mahasiswanya saja yang merasa bosan atau jenuh, dosen pun merasakan hal sama. Untuk mengantisipasi rasa jenuh tersebut mayoritas dosen memadatkan materinya atau bahkan hanya melaksanakan perkuliahan sebulan sekali dengan menggabungkan mahasiswa untuk mata kuliah yang sifatnya wajib umum seperti Pendidikan Pancasila, Pendidikan

Kewarganegaraan, Ke-PGRI-an, dll.

5. Mana yang anda pilih ? pembelajaran tatap muka langsung atau pembelajaran daring ?
Pertanyaan ini diajukan untuk mengetahui keinginan mahasiswa dalam pembelajaran di masa pandemi Covid-19. Pilihannya adalah full daring, sebagian daring, dan full tatap muka. Pertanyaan ini diajukan agar peneliti bisa menympulkan hasil temuannya di lapangan terkait efektivitas pembelajaran daring di masa pandemi Covid-19. Jika mayoritas responden menjawab full daring berarti pembelajaran daring ini sangat efektif dan disukai oleh mahasiwa, namun sebaliknya jika mayoritas responden menjawab full tatap muka, berarti pembelajaran daring ini tidak efektif dan tidak menyenangkan. Berikut adalah hasil survei terhadap mahasiswa mengenai keinginan mereka di dalam melaksanakan perkuliahan:

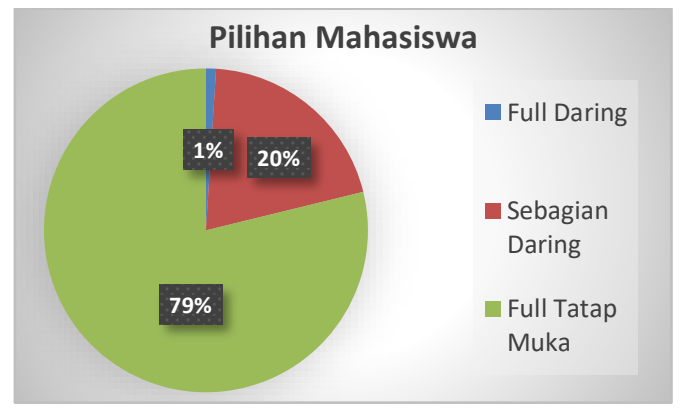

Gambar 5. Pilihan Mahasiswa Terhadap Metode Perkuliahan

Berdasarkan gambar 5 tentang Pilihan Mahasiswa Terhadap Metode Perkuliahan menunjukan hasil $79 \%$ responden menginginkan perkuliahan tatap muka, 20\% responden menginginkan sebagian perkuliahan secara daring, dan hanya $1 \%$ responden yang menginginkan pembelajaran daring sepenuhnya. Hal ini membuktikan bahwa mahasiswa tidak menginginkan pembelajaran daring secara terus menerus.

Dari hasil temuan di lapangan, peneliti menemukan permasalahan dalam pembelajaran daring di masa pandemi Covid-19. Pertama, sumber daya manusianya masih lemah dalam hal ini para dosen belum sepenuhnya memiliki kemampuan dalam mengoprasikan teknologi 
informasi terutama dosen yang sudah berusia lanjut. Lain halnya dengan dosen yang masih muda mampu beradaptasi dengan cepat dalam membaca situasi di lapangan. Kedepan perlu adanya pendidikan dan pelatihan khusus bagi dosen untuk meningkatkan kompetensinya.

Kedua, infrastruktur kita masih belum memadai terutama dalam hal pemerataan koneksi jaringan internet. Tentu saja bagi mahasiswa yang berada di perkotaan tidak menjadi masalah, lain halnya dengan mahasiswa yang memilih mudik ke kampung halaman yang berada di wilayah pegunungan misalnya, sehingga internet di daerahnya tidak bisa diakses sama sekali.

Ketiga, tidak semua mata kuliah bisa diajarkan secara online. Hanya mata kuliah yang sifatnya teoretis yang bisa dilaksanakan secara daring, untuk mata kuliah vokasi atau keterampilan yang mengharuskan praktek langsung maka tidak dapat dilaksanakan secara online, sebagai contoh mata kuliah Praktek Pengenalan Lapangan di Fakultas Keguruan dan Ilmu Pendidikan yang mengharuskan mahasiswanya terjun langsung ke sekolah.

\section{SIMPULAN}

Berdasarkan hasil temuan dan pembahasan dapat disimpulkan bahwa pembelajaran daring secara terus menerus bagi mahasiswa Universitas PGRI Yogyakarta sangat tidak efetif, hal ini disebabkan oleh rasa bosan secara berulang sehingga mencapai titik jenuh. Selain itu materi yang mampu di serap mahasiswa kurang dari setengahnya, ditambah dengan kemampuan dosen dan mahasiswa dalam menggunakan internet yang masih rendah. Dengan demikian pembelajaran daring dirasa cukup efektif manakala hanya dilakukan sewaktu-waktu tidak terus menerus selama 1 semester. Bisa kita bayangkan dalam 1 semester ada kurang lebih 10 mata kuliah yang diampu dengan total 15 pertemuan sehingga total seorang mahasiswa kurang lebih harus berhadapan dengan layar komputernya sebanyak 150 kali. Kedepan pembelajaran daring hanya boleh dilakukan dalam kondisi tertentu yang tidak memungkinkan untuk tatap muka seperti terjadi bencana alam dan dibarengi dengan peningatan profesionalisme tenaga pengajarnya dalam penggunaan beragam aplikasi daring sehingga pembelajaran tidak semakin membosankan.

\section{DAFTAR PUSTAKA}

Aan Widiyono. (2020). Efektifitas Perkuliahan Daring (Online) pada Mahasiswa PGSD di Saat Pandemi Covid 19. Jurnal Pendidikan, 8(2), 169-177.

Ahmad, I. F. (2020). Alternative Assessment in Distance Learning in Emergencies Spread of Coronavirus Disease ( Covid19 ) in Indonesia. Jurnal Pedagogik, 07(01), 195-222.

Arizona, K., Abidin, Z., \& Rumansyah, R. (2020). Pembelajaran Online Berbasis Proyek Salah Satu Solusi Kegiatan Belajar Mengajar Di Tengah Pandemi Covid-19. Jurnal Ilmiah Profesi Pendidikan, 5(1), 64-70. https://doi.org/10.29303/JIPP.V5I1.111

Darmalaksana, W., Hambali, R. Y. A., Masrur, A., \& Muhlas. (2020). Analisis Pembelajaran Online Masa WFH Pandemic Covid-19 sebagai Tantangan Pemimpin Digital Abad 21. Karya Tulis Ilmiah (KTI) Masa Work From Home (WFH) Covid-19 UIN Sunan Gunung Djati Bandung Tahun 2020, 1(1), 1-12.

Ferdiana, S. (2020). Persepsi Mahasiswa Tentang Penggunaan Media Daring Pada Program S1 Ilmu Gizi Sekolah Tinggi Ilmu Kesehatan Surabaya Selama Masa Pandemi Corona Virus Disease (COVID19). Indonesian Journal of Science Learning, 1(1), 5-12.

Handarini, O. I., \& Wulandari, S. S. (2020). 
Pembelajaran Daring Sebagai Upaya Study From Home ( SFH ) Selama Pandemi Covid 19. Jurnal Pendidikan Administrasi Perkantoran (JPAP), 8(3), 496-503.

Hikmat, Hermawan, E., Aldim, \& Irwandi. (2020). Efektivitas Pembalajaran Daring Selama Masa Pandemi Covid-19: Sebuah Survey Online. Digital Library, UIN SUnan Gung Djati, Bandung, 1-7. http://digilib.uinsgd.ac.id/30625/

Kusnayat, A., Sumarni, N., Mansyur, A. S., Zaqiah, Q. Y., \& Bandung, U. T. (2020). Pengaruh Teknologi Pembelajaran Kuliah Online Di Era Covid-19 Dan Dampaknya Terhadap Mental Mahasiswa. EduTeach: Jurnal Edukasi Dan Teknologi Pembelajaran, 1(2), 153-165.

M Ardi Sulata \& Abdul Aziz Hakim. (2020). Gambaran Perkuliahan Daring Mahasiswa Ilmu Keolahragaan UNESA Di Masa Pandemi Covid-19. Jurnal Kesehatan Olahraga, 8(3), 147-156.

Mulawarman, W. G. (2020). Persoalan Dosen dan Mahasiswa Masa Pandemik Covid 19: Dari Gagap Teknologi Hingga Mengeluh Boros Paket Data. Prosiding Seminar Nasional Hardiknas Universitas Mulawarman, 37-46.

Mustakim. (2020). Efektivitas Pembelajaran Daring Menggunakan Media Online Selama Pandemi Covid-19 Pada Mata Pelajaran Matematika. Al Asma: Journal of Islamic Education, 2(1), 1-12.

Ni Komang Suni Astini. (2020). Pemanfaatan Teknologi Informasi Dalam Pembelajaran Tingkat Sekolah Dasar Pada Masa Pandemi Covid-19. Jurnal Lampuhyang, 11(2), 13-25.

Novia Nur Kharisma dkk. (2020). Gambaran Kebutuhan Pembelajaran Daring PKBM Budi Utama Surabaya Pada Masa Pandemi Covid-19. Jurnal Pendidikan Non Formal, 15(1), 38-44.

Nurgiansah, T. H. (2019). Pemutakhiran Kurikulum PKn di Era Revolusi Industri 4.0. Prosiding Seminar
Kewarganegaraan Universitas Negeri Medan, 1(1), 95-102.

Nurgiansah, T. H. Y. P. (2020). Pelatihan Penggunaan Model Pembelajaran Jurisprudensial Pada Guru Di KB TK Surya Marta Yogyakarta. KUAT: Keuangan Umum Dan Akuntansi Terapan. PKNSTAN, 2(1), 52-57.

Purwanti, E., \& Krisnadi, I. (2020). Implementasi Sistem Perkuliahan Daring Berbasis ICT Dalam Masa Pandemi Wabah Covid -19. Pascasarjana Program Magister Teknik Elektro Universitas Mercu Buana, 1(1), 1-12.

Rachmat, A., \& Krisnadi, I. (2020). Analisis Efektifitas Pembelajaran Daring ( Online ) Untuk Siswa SMK Negeri 8 Kota Tangerang Pada Saat Pandemi Covid 19. Magister Teknik Elektro Universitas Mercu Buana, 1-7.

Sadikin, A., Hamidah, A., Pinang, K., Jl, M., Ma, J., Km, B., Indah, M., Jaluko, K., Kode, K. M., \& Indonesia, P. (2020). Pembelajaran Daring di Tengah Wabah Covid-19 ( Online Learning in the Middle of the Covid-19 Pandemic ). BIODIK: Jurnal Ilmiah Pendidikan Biologi, 6(2), 214-224.

Satrio, Y. D., Handayani, S., Abbas, M. H. I., \& Kustiandi, J. (2020). Studi Komparasi Metode Pembelajaran dalam Meningkatkan Literasi Keuangan di Masa Pandemi Covid-19. Jurnal Pendidikan Ekonomi Undiksha, 12(1), 29-35.

Sherina, S. Z. \& W. (2020). Efektivitas Pembelajaran Basis Online Di IAIN Tulungagung Dengan Adanya Kebijakan Physical Distancing Era Pandemi Covid 19. Jurnal Geram (Gerakan Aktif Menulis), 8(1), 83-89.

Simatupang, N. I., Rejeki, S., Sitohang, I., Patricia, A., Simatupang, I. M., Pendidikan, P., Universitas, K., \& Indonesia, K. (2020). Efektivitas Pelaksanaan Pengajaran Online Pada Masa Pandemi Covid-19 Dengan Metode 
375 Efektivitas Pembelajaran Daring di Masa Pandemi COVID 19 Bagi Mahasiswa Universitas PGRI Yogyakarta - Jagad Aditya Dewantara, T Heru Nurgiansah

DOI: https://doi.org/10.31004/basicedu.v5i1.669

Survey Sederhana. Jurnal Dinamika

Pendidikan, 13(2), 1-7.

https://doi.org/10.33541/jdp.v13i2.1754

Solviana, M. D. (2020). Pemanfaatan

Teknologi Pendidikan di Masa Pandemi

Covid-19: Penggunaan Fitur Gamifikasi

Daring di Universitas Muhammadiyah

Pringsewu Lampung. Al-Jahiz: Journal of Biology Education Research, 1(1), 114.

Suhada, I., Kurniati, T., Pramadi, A., Listiawati, M., Biologi, P. P., Gunung, S., \& Bandung, D. (2020). Pembelajaran Daring Berbasis Google Classroom Mahasiswa Pendidikan Biologi Pada Masa Wabah Covid-19. Digital Library UIN Sunan Gunung Jati, 2019, 1-9. http://digilib.uinsgd.ac.id/30584/

Titi Rohaeti; Sumliyah. (2020). Respon Mahasiswa Pendidikan Matematika Dalam Penggunaan Google Classroom di Era Covid 19. Jurnal Integral, 11(1), 60 68.

https://doi.org/10.11428/jhej1987.42.189

Yensy, N. A. (2020). Efektifitas Pembelajaran Statistika Matematika melalui Media Whatsapp Group Ditinjau dari Hasil Belajar Mahasiswa (Masa Pandemik Covid 19). Jurnal Pendidikan Matematika Raflesia, 05(02), 65-74. https://ejournal.unib.ac.id/index.php/jpmr 